\title{
EFEKTIVITAS BERBAGAI FORMULASI RIZOBAKTERI SEBAGAI BIOHERBISIDA PADA PERTANAMAN KEDELAI (Glycine max (L.) Merril)
}

\section{THE EFFECTIVENESS OF VARIOUS FORMULATIONS RHIZOBACTERIA AS BIOHERBICIDE IN SOYBEAN (Glycine max (L.) Merrill)}

\author{
Afiati Bahrawi ${ }^{1}$, La Karimuna ${ }^{{ }^{*}}$, Muhidin ${ }^{2}$ \\ ${ }^{1)}$ Alumni Program Studi Agronomi Program Pascasarjana UHO \\ ${ }^{2)}$ Dosen Program Studi Agronomi Program Pascasarjana UHO
}

Diterima: 22 Desember 2017/Disetujui: 28 Juli 2018

\begin{abstract}
ABSTRACK
The purpose of this research was to study the effectiveness of various formulations rhizobacteria as bioherbicide in soybean. This research was conducted at the Agrotechnology Laboratory Unit Agronomy and Field Laboratory, Faculty of Agriculture Halu Oleo university, Kendari from March to June 2016.

This research was arranged on randomized complete block design (CBD), which consisted of seven treatments that are P0 (Control), P1 (Bacillus sp. $\mathrm{A}_{05}+$ water), P2 (Bacillus sp. $\mathrm{A}_{05}+$ talc), $\mathrm{P} 3$ (Bacillus sp. $\mathrm{A}_{05}+$ husk charcoal powder), P4 (P. aeruginosa $\mathrm{A}_{08}+$ water), P5 (P. aeruginosa $\mathrm{A}_{08}+$ talc), P6 (P. aeruginosa $\mathrm{A}_{08}+$ husk charcoal powder). The treatments was repeated three times so that there were 21 experimental units. Weed vegetation were analyzed using quadratic metode, quadrant size used was $1 \times 1 \mathrm{~m}^{2}$, observations were made one time when the soybean was $21 \mathrm{HST}$. The soybean data were analyzed using of analysis variance followed by Duncan's Multiple Range Test if the treatments was significant.

The results showed that treatment of formulations rhizobacteria P6 namely P. aeruginosa $\mathrm{A}_{08}$ in the husk charcoal powder carrier formulation was the best among all 5 other formulations, that could be seen in the weeds vegetation analysis data results, showed that $\mathrm{P}$. aeruginosa $\mathrm{A}_{08}$ in the husk charcoal powder carrier formulation could suppress the growth of Cleome rutidosperma D.C and Cyperus rotundus $\mathrm{L}$. which was the dominant weeds in soybean. Husk charcoal powder was able to improve the suitability of rhizobacteria $P$. aeruginosa $\mathrm{A}_{08}$ as bioherbisida in the field so that they could worked more effectively as bioherbisida than other treatments.
\end{abstract}

Keywords: Bioherbicides, formulation rhizobacteria, Glycine max (L.) Merrill

\section{ABSTRAK}

Tujuan penelitian ini adalah untuk mempelajari efektivitas formulasi rizobakteri sebagai bioherbisida pada pertanaman kedelai. Penelitian ini dilaksanakan di Laboratorium Agroteknologi Unit Agronomi dan Laboratorium Lapangan Fakultas Pertanian Universitas Halu Oleo Kendari dan telah dilaksanakan sejak Maret 2016 sampai Juni 2016.

Penilitian ini disusun berdasarkan rancangan acak kelompok (RAK) yang terdiri dari 7 perlakuan yaitu P0 (Kontrol), P1 (Bacillus sp. $\mathrm{A}_{05}+$ air), P2 (Bacillus sp. $\mathrm{A}_{05}+$ talek), P3 (Bacillus sp. $\mathrm{A}_{05}+$ serbuk arang sekam), P4 (P. aeruginosa $\mathrm{A}_{08}+$ air), P5 (P. aeruginosa $\mathrm{A}_{08}+$ talek), P6 (P. aeruginosa $\mathrm{A}_{08}+$ serbuk arang sekam). Perlakuan diulang sebanyak tiga kali sehingga terdapat 21 unit percobaan. Vegetasi gulma dianalisis menggunakan metode kuadrat, ukuran kuadrat yang digunakan yaitu $1 \times 1 \mathrm{~m}^{2}$, pengamatan dilakukan 1 kali pada saat tanaman kedelai berumur $21 \mathrm{HST}$. Data hasil pengamatan tanaman kedelai dianalisis menggunakan sidik ragam dan dilanjutkan dengan Uji Jarak Berganda Duncan jika perlakuan berpengaruh nyata.

Hasil penelitian menunjukkan bahwa perlakuan P6 yaitu formulasi rizobakteri $P$. aeruginosa $\mathrm{A}_{08}$ dalam bahan pembawa serbuk arang sekam merupakan formulasi terbaik diantara ke-5 formulasi lainnya, dapat dilihat pada data hasil analisis vegetasi gulma yang menunjukkan bahwa perlakuan P. aeruginosa $\mathrm{A}_{08}+$ serbuk arang sekam mampu menekan pertumbuhan gulma Cleome rutidosperma dan Cyperus rotundus yang merupakan gulma dominan pada pertanaman kedelai. Serbuk arang sekam mampu meningkatkan stabilitas rizobakteri P. aeruginosa $\mathrm{A}_{08}$ sebagai bioherbisida di lapangan sehingga mampu bekerja lebih efektif sebagai bioherbisida dibandingkan perlakuan lainnya.

\section{PENDAHULUAN}

Kedelai (Glycine $\max (\mathrm{L}$.$) Merril) adalah$ komoditas tanaman pangan terpenting ketiga setelah padi dan jagung di Indonesia. Kedelai merupakan sumber protein nabati yang relatif murah, sehingga dapat dijangkau oleh seluruh lapisan masyarakat di Indonesia. Beberapa produk olahan yang dihasilkan dari kedelai antara lain adalah tempe, tahu, es krim,

\footnotetext{
${ }^{*}$ Penulis untuk korespondensi. Emaile-mail: lkarimuna@hotmail.com
} 
susu kedelai, tepung kedelai, dan minyak kedelai. Kedelai mengandung protein $31-35 \%$, karbohidrat 0,9-2,6\% dan lemak 16-24\%, asam linoleat 53,86\% dan asam linolenat $7,16 \%$. Asam linoleat dan linolenat merupakan asam esensial untuk tubuh yang berperan dalam pengaturan metabolisme kolesterol, mengatur tekanan darah dan mencegah penyakit jantung (Isa, 2011).

Banyaknya manfaat yang dapat diperoleh dari kedelai dan peningkatan jumlah penduduk di Indonesia menyebabkan permintaan kedelai mengalami peningkatan dari tahun ke tahun. Produksi kedelai di Indonesia pada tahun 2011 sebesar 851.286 ton dengan luas panen 622.254 ha (produktivitas 1,37 $\mathrm{t} \mathrm{ha}^{-1}$ ), tahun 2012 sebesar 843.153 ton dengan luas panen 567.624 ha (produktivitas 1,49 $\mathrm{t} \mathrm{ha}^{-1}$ ), mengalami penurunan produksi pada tahun 2013 menjadi 779.992 ton dengan luas panen 550.793 ha (produktivitas 1,42 t $\mathrm{ha}^{-1}$ ), tahun 2014 mengalami peningkatan produksi menjadi 954.994 ton dengan luas panen 615.685 ha (produktivitas 1,56 ton $\mathrm{ha}^{-1}$ ) tahun 2015 juga mengalami peningkatan yaitu 998.866 ton dengan luas panen 640.351 ha (produktivitas 1,60 $\mathrm{t} \mathrm{ha}^{-1}$ ).

Berdasarkan data di atas maka dapat dilihat bahwa produksi kedelai nasional mengalami kecenderungan penurunan dalam lima tahun terakhir. Penurunan areal luas panen merupakan salah satu penyebab rendahnya produksi kedelai dalam negeri. Faktor lain yang menjadi penyebab turunnya produksi kedelai adalah adanya kendala dalam teknik budidaya. Salah satu kendala dalam teknik budidaya adalah akibat gangguan gulma yang dapat menurunkan hasil tanaman kedelai sebesar 91\% jika tidak dilakukan pengendalian gulma sejak awal (Sembodo, 2010).

Pengendalian gulma yang dilakukan sering kali menggunakan bahan kimia atau herbisida, tetapi ini merugikan bagi lingkungan dan organisme lain, karena residunya tanah dan perairan sehingga dapat mengganggu keseimbangan ekosistem. Salah satu upaya yang dapat dilakukan untuk mengendalikan gulma sehingga dapat meningkatkan produksi kedelai adalah menggunakan teknik pengendalian hayati, yaitu dengan rizobakteri yang dapat menekan pertumbuhan gulma tetapi tidak merugikan kedelai yang disebut deleterious rhizobacteria (DRB) (Kremer, 2006).

Kemampuan bakteri ini sebagai agens pengendali hayati gulma karena kemampuannya mengeluarkan senyawa metabolit sekunder yaitu asam sianida (HCN) dan Indole acetid acid (IAA). Asam sianida merupakan senyawa toksin yang dihasilkan oleh rizobakteri yang dapat mengendalikan pertumbuhan gulma dan IAA merupakan hormon tumbuh yang jika berada dalam konsentrasi yang tinggi makan menghambat pertumbuhan gulma sehingga keduanya dapat dijadikan sebagai indikator bioherbisida. Jenis bakteri yang telah banyak dilaporkan sebagai DRB adalah Pseudomonas fluorescence strain D7 (O'Hara, 2005), dan Pseudomonas putida ATH2IRI/9 (Kremer dan Souissi, 2001).

Hasil penelitian Hisnawati (2014) mendapatkan 45 jenis isolat rizobakteri yang diisolasi dari 9 jenis gulma, sebagian dari isolat tersebut memiliki kemampuan menghasilkan IAA, memfiksasi nitrogen bebas dari udara, melarutkan fosfat serta menghasilkan senyawa asam sianida $(\mathrm{HCN})$. Asam sianida merupakan senyawa toksin yang dihasilkan oleh rizobakteri yang dapat mengendalikan pertumbuhan gulma atau dapat dijadikan sebagai indicator bioherbisida.

Efektivitas rizobakteri sebagai bioherbisida ditentukan oleh ketahanan hidupnya dalam penyimpanan jangka panjang dan juga kelangsungan hidup rizobakteri tersebut di lapangan. Oleh karena itu, suspensi rizobakteri harus disimpan dalam bahan tertentu dan harus disiapkan sebagai formulasi untuk mempermudah aplikasi, penyimpanan, komersialisasi dan penggunaan lapangan. Jorjani et al. (2012) menyatakan bahwa suspensi $P$. fluorescens dengan konsentrasi $40 \mathrm{ml}$ dengan kepadatan koloni $109 \mathrm{CFU}$ ml-1 dicampur dengan talek $(100 \mathrm{~g})$ and $\mathrm{CMC}(1 \mathrm{~g}), 60$ hari setelah aplikasi P. fluorescens masih mampu hidup dan tidak mengurangi efektivitasnya. Tujuan penelitian ini adalah untuk mempelajari efektivitas formulasi rizobakteri sebagai bioherbisida pada pertanaman kedelai.

\section{BAHAN DAN METODE}

Penelitian ini dilaksanakan di Laboratorium Agroteknologi Unit Agronomi dan Laboratorium Lapangan Fakultas Pertanian Universitas Halu Oleo Kendari dan telah dilaksanakan sejak Maret 2016 sampai Juni 2016.

Bahan yang digunakan dalam penelitian ini adalah benih kedelai varietas Argomulyo (deskripsi terlampir pada Lampiran 2.), isolat rizobakteri indigenous Bacillus sp. $\left(\mathrm{A}_{05}\right)$ dan Pseudomonas aeruginosa $\left(\mathrm{A}_{08}\right)$ (koleksi Dr. Ir. Tresjia C. Rakian, M.P), aquades, pupuk organik, natrium hipoklorit, agar, tissue, spiritus, plastik wrap, aluminium foil, kertas label, alkohol 70\%, glycerol, Trypthic Soy Broth (TSB), talek dan arang sekam. Alat-alat yang digunakan dalam penelitian ini adalah baki, pacul, parang, gembor, traktor, oven, timbangan analitik, shaker, autoclave, laminar air flow cabinet, sekop, erlenmeyer, jarum ose, cawan petri, lampu bunsen, gelas ukur, gelas kimia, stirrer, corong, kamera, 
botol scott, batang penyebar, mistar dan alat tulis menulis.

Pengamatan gulma dilakukan dengan analisis vegetasi, analisis ini dilakukan untuk menentukan kombinasi jenis vegetasi dari yang paling dominan hingga yang jarang. Metode yang digunakan adalah metode yang dihitung dalam satuan kuadrat dengan ukuran kuadrat yaitu $1 \times 1 \mathrm{~m}^{2}$. Pengamatan dilakukan satu kali pada atau saat tanaman kedelai berumur 21 HST. Analisis vegetasi gulma meliputi kerapatan mutlak (KM), kerapatan nisbi (KN), dominansi mutlak (DM), dominansi nisbi (DM), indeks nilai penting (INP) dan SDR. Data hasil pengamatan tanaman kedelai dianalisis dengan menggunakan analisis Ragam atau ANOVA. Hasil analisis yang menunjukkan Fhitung $>$ Ftabel dilanjutkan dengan Uji Jarak Berganda Duncan (DMRT) pada taraf nyata $\alpha=0.05$.

\section{HASIL}

Hasil pengamatan pengaruh berbagai formulasi rizobakteri terhadap gulma disajikan pada Tabel 1 , Tabel 2, dan Tabel 3.

Tabel 1. Hasil pengamatan pengaruh berbagai formulasi rizobakteri terhadap kerapatan mutlak gulma 35 HST.

\begin{tabular}{|c|c|c|c|c|c|c|c|}
\hline \multirow{2}{*}{ Jenis Gulma } & \multicolumn{7}{|c|}{ Rerata kerapatan mutlak (individu) } \\
\hline & $\mathrm{P} 0$ & $\mathrm{P} 1$ & $\mathrm{P} 2$ & P3 & $\mathrm{P} 4$ & P5 & P6 \\
\hline Cleome rutidosperma D.C & 214 & 102 & 83 & 95 & 85 & 83 & 28 \\
\hline Cyperus rotundus $L$. & 103 & 89 & 53 & 72 & 42 & 56 & 30 \\
\hline Chromolaena odorata (L.) King & 122 & - & - & - & - & - & - \\
\hline Boreria sp. & 91 & 71 & 26 & 73 & 44 & 85 & 70 \\
\hline Amaranthus sp. & 11 & - & - & - & - & - & - \\
\hline Digitaria sp. & 12 & - & - & 7 & 7 & - & - \\
\hline Ageratum conyzoides L. & 71 & 50 & 66 & - & 43 & 37 & 30 \\
\hline Eleusine indica (L.) Gaertn & 12 & - & - & - & - & - & - \\
\hline Paspalum sp. & 73 & - & - & - & 4 & - & - \\
\hline Blumea sp. & 4 & - & - & - & - & - & - \\
\hline Asystasia $\mathrm{sp}$. & - & 1 & 12 & - & - & 35 & - \\
\hline Echinocloa colonum (L.) Link & - & 30 & - & 16 & - & 20 & 19 \\
\hline Cynodon dactylon (L.) Pers & - & 38 & 14 & 21 & 35 & 25 & 23 \\
\hline Scoparia dulcis L. & - & - & 5 & 26 & - & - & 13 \\
\hline Total & 713 & 381 & 259 & 310 & 260 & 341 & 213 \\
\hline
\end{tabular}

Keterangan : $\mathrm{P} 0=$ Kontrol (tanpa aplikasi rizobakteri); $\mathrm{P} 1=$ Bacillus sp. $\mathrm{A}_{05}+$ air; $\mathrm{P} 2=$ Bacillus $\mathrm{sp}$. $\mathrm{A}_{05}+$ talek; $\mathrm{P} 3=$ Bacillus sp. $\mathrm{A}_{05}+$ serbuk arang sekam; $\mathrm{P} 4=$ P. aeruginosa $\mathrm{A}_{08}+$ air; $\mathrm{P} 5=P$. aeruginosa $\mathrm{A}_{08}+$ talek; $\mathrm{P} 6=P$. aeruginosa $\mathrm{A}_{08}+$ serbuk arang sekam.

Nilai kerapatan berasal dari jumlah jenis gulma dalam petak contoh. Berdasarkan hasil pengamatan, semua formulasi rizobakteri mampu menurunkan total kerapatan gulma jika dibandingkan dengan kontrol. Perlakuan P0 kerapatan tertinggi terdapat pada gulma Cleome rutidosperma D.C. dengan nilai 214 individu, perlakuan P1 yaitu 102 individu, P3 yaitu 95 individu, perlakuan P2 dan P5 memiliki jumlah yang sama yaitu 83 individu dan jumlah terendah terdapat pada perlakuan P6 yaitu 28 individu, dengan demikian perlakuan P6 merupakan perlakuan yang terbaik karena mampu menghambat pertumbuhan gulma Cleome rutidosprema D.C. Jumlah gulma Cyperus rotundus L. tertinggi terdapat pada perlakuan P0 Kontrol yaitu 103 individu, perlakuan P1 yaitu 89 individu, P3 yaitu 72 individu, perlakuan P5 yaitu 56 individu, perlakuan P2 yaitu 53 individu dan perlakuan P6 merupakan perlakuan dengan jumlah gulma Cyperus rotundus L. terendah yaitu 30 individu. Perlakuan P6 merupakan perlakuan terbaik yang dapat menghambat pertumbuhan gulma Cyperus rotundus L. Gulma Cromolaena odorata (L.) King hanya tumbuh pada perlakuan P0 dengan jumlah 122 individu, dengan demikian semua perlakuan formulasi rizobakteri mampu menghambat pertumbuhan ini. Gulma Boreria sp. memiliki jumlah paling banyak pada perlakuan P0 dengan jumlah 91 individu, kemudian perlakuan P5 yaitu 85 individu, perlakuan P3 yaitu 73 individu, perlakuan P6 yaitu 70 individu, perlakuan P4 yaitu 44 individu dan jumlah terendah atau perlakuan terbaik yang dapat menghambat pertumbuhan gulma ini yaitu perlakuan $\mathrm{P} 2$ yaitu 26 
individu. Gulma Amaranthus sp. hanya terdapat pada perlakuan P0 dengan jumlah 11 individu dengan demikian semua perlakuan aplikasi formulasi rizobakteri mampu menghambat pertumbuhan gulma ini. Gulma Digitaria sp. terdapat pada perlakuan P0 sebanyak 12 individu, dan pada perlakuan P3 dan P4 dengan jumlah yang sama yaitu 7 individu, sedangkan pada perlakuan P1, P2, P5 dan P6 yaitu 0 individu maka perlakuan P1, P2, P5 dan P6 mampu menghambat pertumbuhan gulma ini.

Gulma Ageratum conyzoides L. terdapat pada perlakuan P0 dengan jumlah 71 individu, kemudian perlakuan P2 dengan jumlah 66 individu, perlakuan $\mathrm{P} 1$ yaitu 50 individu, perlakuan P4 yaitu 43 individu, perlakuan P5 yaitu 37 individu, perlakuan P6 yaitu 30 individu, perlakuan P3 yaitu 0 individu, maka perlakuan P3 merupakan perlakuan terbaik yang mampu menghambat pertumbuhan gulma ini. Gulma Eleusine indica (L.) Gaertn hanya terdapat pada perlakuan P0 yaitu 12 dengan demikian bahwa P1, P2, P3, P4, P5 dan P6 mampu menghambat pertumbuhan ini. Gulma Paspalum sp. terdapat pada perlakuan P0 sebanyak 73 individu dan pada perlakuan P4 sebanyak 4 individu, pada perlakuan P1, P2, P3, P5 dan P6 yaitu 0 individu, maka perlakuan P1, P2, P3, P5 dan P6 merupakan perlakuan terbaik yang mampu menghambat pertumbuhan gulma ini. Gulma Blumea sp. hanya terdapat pada perlakuan kontrol sebanyak 4 individu, maka perlakuan P1, P2, P3, P4, P5 dan P6 merupakan perlakuan terbaik yang dapat mengendalikan gulma ini. Gulma Asystasia sp. jumlah tertinggi terdapat pada perlakuan P5 sebanyak 35 individu, pada perlakuan P2 terdapat sebanyak 12 individu dan pada perlakuan P1 terdapat sebanyak 1 individu, pada perlakuan P0, tetapi perlakuan terbaik adalah perlakuan P3, P4 dan P6 karena pada perlakuan ini gulma tersebut tidak tumbuh jika dibandingkan dengan perlakuan P5, P2 dan P1.

Gulma Echinocloa colonum (L.) Link jumlah tertinggi terdapat pada perlakuan P1 sebanyak 38 individu, perlakuan P5 sebanyak 20 individu, perlakuan P6 sebanyak 19 individu, perlakuan P3 sebanyak 16 individu, pada perlakuan P0 yaitu 0 individu, tetapi perlakuan terbaik adalah perlakuan P2 dan P4 karena gulma ini tidak tumbuh pada perlakuan tersebut. Gulma Cynodon dactylon (L.) Pers, jumlah tertinggi terdapat pada perlakuan P1 sebanyak 38 individu, perlakuan P4 sebanyak 35 individu, perlakuan P5 sebanyak 25 individu, perlakuan P6 sebanyak 23 individu, perlakuan P3 sebanyak 21 individu, perlakuan P2 sebanyak 14 individu, sedangkan pada perlakuan P0 gulma ini tidak tumbuh, tetapi berdasarkan jumlahnya pada setiap perlakuan maka perlakuan terbaik yang dapat mengendalikan gulma ini adalah perlakuan P2. Gulma Scoparia dulcis L. tidak terdapat pada perlakuan P0. Jumlah tertinggi terdapat pada perlakuan P3 sebanyak 26 individu, perlakuan P6 sebanyak 13 individu dan perlakuan P2 sebanyak 5 individu dan perlakuan terbaik yang dapat mengendalikan gulma ini adalah perlakuan P1, P4 dan P5.

Tabel 2. Hasil pengamatan pengaruh berbagai formulasi rizobakteri terhadap dominansi mutlak gulma 35 HST.

\begin{tabular}{|c|c|c|c|c|c|c|c|}
\hline \multirow{2}{*}{ Jenis Gulma } & \multicolumn{7}{|c|}{ Rerata dominansi mutlak (gr) } \\
\hline & P0 & P1 & P2 & P3 & P4 & P5 & P6 \\
\hline Cleome rutidosperma D.C & 42,57 & 39,00 & 17,36 & 21,23 & 18,01 & 17,36 & 8,31 \\
\hline Cyperus rotundus $L$. & 17,20 & 15,15 & 10,21 & 13,64 & 8,62 & 11,20 & 5,36 \\
\hline Chromolaena odorata (L.) King & 11,93 & - & - & - & - & - & - \\
\hline Boreria sp. & 16,89 & 10,92 & 5,15 & 11,11 & 5,44 & 14,06 & 8,92 \\
\hline Amaranthus sp. & 0,47 & - & - & - & - & - & - \\
\hline Digitaria sp. & 1,65 & - & - & 0,23 & 0,23 & - & - \\
\hline Ageratum conyzoides $\mathrm{L}$. & 15,53 & 12,72 & 14,50 & - & 15,73 & 10,20 & 8,50 \\
\hline Eleusine indica (L.) Gaertn & 0,60 & - & - & - & - & - & - \\
\hline Paspalum sp. & 6,11 & - & - & - & 2,27 & - & - \\
\hline Blumea sp. & 0,19 & - & - & - & - & - & - \\
\hline Asystasia sp. & - & 0,31 & 1,73 & - & - & 2,86 & - \\
\hline Echinocloa colonum (L.) Link & - & 5,16 & - & 2,12 & - & 3,03 & 2,03 \\
\hline Cynodon dactylon (L.) Pers & - & 7,24 & 2,30 & 4,05 & 6,15 & 4,8 & 4,3 \\
\hline Scoparia dulcis $\mathrm{L}$. & - & - & 0,14 & 3,08 & - & - & 0,82 \\
\hline Total & 113,14 & 90,50 & 51,39 & 55,46 & 56,45 & 63,51 & 38,24 \\
\hline
\end{tabular}

Keterangan : P0= Kontrol (tanpa aplikasi rizobakteri); $\mathrm{P} 1=$ Bacillus sp. $\mathrm{A}_{05}+$ air; $\mathrm{P} 2=$ Bacillus sp. $\mathrm{A}_{05}+$ talek; $\mathrm{P} 3=$ Bacillus sp. $\mathrm{A}_{05}+$ serbuk arang sekam; $\mathrm{P} 4=$ P. aeruginosa $\mathrm{A}_{08}+$ air; $\mathrm{P} 5=P$. aeruginosa $\mathrm{A}_{08}+$ talek; $\mathrm{P} 6=P$. aeruginosa $\mathrm{A}_{08}+$ serbuk arang sekam. 


\section{J. Berkala Penelitian Agronomi 6 (2) : 37 - 43 (2018)}

Nilai dominansi mutlak tertinggi untuk gulma Cleome rutidosperma D.C terdapat pada perlakuan P0 yaitu sebesar 42,57 g, selanjutnya adalah perlakuan P1 sebesar $39 \mathrm{~g}$, perlakuan P3 sebesar 21,23 g, perlakuan P4 sebesar 18,01 g, perlakuan P2 dan P5 yaitu 17,36 g dan dominansi mutlak terendah terdapat pada perlakuan P6 yaitu 8,31 g. Dominansi mutlak tertinggi gulma Cyperus rotundus L. terdapat pada perlakuan P0 sebesar 17,20 g, kemudian perlakuan sebesar $15,15 \mathrm{~g}$, perlakuan P3 sebesar 13,64 g, perlakuan P5 sebesar 11,20 g, perlakuan P2 sebesar 10,21 g, perlakuan P4 sebesar 8,62 dan dominansi terendah terdapat pada perlakuan P6 sebesar $8,31 \mathrm{~g}$.

Gulma Cromolaena odorata L. terdapat pada perlakuan P0 dengan nilai dominansi mutlak sebesar $11,93 \mathrm{~g}$ dan diperlakuan lainnya sebesar $0 \mathrm{~g}$. Nilai dominansi mutlak tertinggi untuk gulma Boreria sp. terdapat pada perlakuan P0 sebesar 16,89 g, kemudian perlakuan P5 sebesar 14,06 g, perlakuan P3 sebesar 11,11 g, perlakuan P1 sebesar 10,92 g, perlakuan P6 sebesar 8,92 g, perlakuan P4 sebesar $5,44 \mathrm{~g}$ dan dominansi terendah terdapat pada perlakuan P2 sebesar 5,15 g. Gulma Amaranthus sp. terdapat pada perlakuan P0 dengan nilai dominansi mutlak sebesar $0,47 \mathrm{~g}$ dan $0 \mathrm{~g}$ diperlakuan lainnya. Nilai dominansi mutlak tertinggi untuk Gulma Digitaria sp. terdapat pada perlakuan P0 sebesar 1,65 g perlakuan P3 dan P4 dengan nilai sama yaitu sebesar 0,23 g, pada perlakuan P1, P2, P5 dan P6yaitu $0 \mathrm{~g}$.

Nilai dominansi mutlak tertinggi untuk gulma Ageratum conyzoides $\mathrm{L}$. terdapat pada perlakuan P4 sebesar 15,73 jika dibandingkan perlakuan P0 yaitu sebesar 15,53 g, kemudian perlakuan P2 sebesar 14,50 g, perlakuan P1 sebesar 12,72 g, perlakuan P5 sebesar 10,20 g, perlakuan P6 sebesar 8,50 g dan pada perlakuan P3 yaitu. Gulma Eleusine indica (L.) Gaertn terdapat pada perlakuan P0 dengan nilai dominansi mutlak sebesar $0,60 \mathrm{~g}$. Nilai dominansi mutlak tertinggi gulma Paspalum sp. terdapat pada perlakuan P0 yaitu sebesar 6,11 dan perlakuan P4 sebesar 2,27 g sedangkan pada perlakuan P1, P2, P3, P5 dan P6 yaitu sebesar 0 g. Gulma Blumea sp. terdapat pada perlakuan P0 sebesar 0,19. Nilai dominansi mutlak tertinggi untuk gulma Asystasia sp. terdapat pada perlakuan P5 sebesar 2,86 g, perlakuan P2 sebesar 1,73 g, perlakuan P1 sebesar 0,31 g, pada perlakuan P0, P3, P4, dan P6 yaitu0 g.

Nilai dominansi mutlak tertinggi gulma Echinocloa colonum (L.) Link terdapat pada perlakuan P1 sebesar 5,16 g, perlakuan P5 sebesar 3,03 g, perlakuan P3 sebesar 2,12 g, perlakuan P6 sebesar 2,03 g, pada perlakuan $\mathrm{P} 0, \mathrm{P} 2$ dan $\mathrm{P} 4$ yaitu 0 g. Nilai dominansi mutlak tertinggi untuk gulma Cynodon dactylon (L.) Pers terdapat pada perlakuan P1 sebesar 7,24 g, perlakuan P4 sebesar 6,15 g, perlakuan P5 sebesar 4,8 g, perlakuan P3 sebesar 4,05 g, perlakuan P2 sebesar 2,30 g, pada perlakuan P0 yaitu 0 g. Nilai dominansi mutlak tertinggi gulma Scoparia dulcis L. terdapat pada perlakuan P3 sebesar 3,08 g, perlakuan P6 yaitu 0,82 g, perlakuan $\mathrm{P} 2$ sebesar 0,14 , perlakuan $\mathrm{P} 0, \mathrm{P} 1, \mathrm{P} 4$ dan $\mathrm{P} 5$ yaitu 0 g.

Tabel 3. Hasil pengamatan pengaruh berbagai formulasi rizobakteri terhadap nilai SDR gulma 35 HST.

\begin{tabular}{lccccccc}
\hline \multirow{2}{*}{ Jenis Gulma } & \multicolumn{7}{c}{ Nilai SDR (\%) } \\
\cline { 2 - 8 } & P0 & P1 & P2 & P3 & P4 & P5 & P6 \\
\hline Cleome rutidosperma D.C & 33,82 & 34,93 & 32,91 & 34,46 & 32,30 & 25,84 & 17,44 \\
Cyperus rotundus L. & 14,82 & 20,05 & 20,17 & 23,91 & 15,71 & 17,03 & 14,05 \\
Chromolaena odorata (L.) King & 13,83 & - & - & - & - & - & - \\
Boreria sp. & 13,85 & 15,35 & 10,03 & 21,79 & 13,28 & 23,53 & 28,10 \\
Amaranthus sp. & 0,98 & - & - & - & - & - & - \\
Digitaria sp. & 1,57 & - & - & 1,34 & 1,55 & - & - \\
Ageratum conyzoides L. & 11,84 & 13,59 & 26,85 & - & 22,20 & 13,46 & 18,16 \\
Eleusine indica (L.) Gaertn & 1,11 & - & - & - & - & - & - \\
Paspalum sp. & 7,82 & - & - & - & 2,78 & - & - \\
Blumea sp. & 0,36 & - & - & - & - & - & - \\
Asystasia sp. & - & 0,30 & 4,00 & - & - & 7,38 & - \\
Echinocloa colonum (L.) Link & - & 6,79 & - & 4,49 & - & 5,32 & 7,11 \\
Cynodon dactylon (L.) Pers & - & 8,99 & 4,94 & 7,04 & 12,18 & 7,44 & 11,02 \\
Scoparia dulcis L. & - & - & 1,10 & 6,97 & - & - & 4,12 \\
\hline \multicolumn{1}{c}{ Total } & 100,00 & 100,00 & 100,00 & 100,00 & 100,00 & 100,00 & 100,00
\end{tabular}

Keterangan : $\mathrm{P} 0=$ Kontrol (tanpa aplikasi rizobakteri); $\mathrm{P} 1=$ Bacillus sp. $\mathrm{A}_{05}+$ air; $\mathrm{P} 2=$ Bacillus $\mathrm{sp}$. $\mathrm{A}_{05}+$ talek; $\mathrm{P} 3=$ Bacillus sp. $\mathrm{A}_{05}+$ serbuk arang sekam; $\mathrm{P} 4=$ P. aeruginosa $\mathrm{A}_{08}+$ air; $\mathrm{P} 5=P$. aeruginosa $\mathrm{A}_{08}+$ talek; $\mathrm{P} 6=P$. aeruginos $\mathrm{A}_{08}+$ serbuk arang sekam. 
Gulma Cleome rutidosperma memiliki nilai SDR tertinggi pada perlakuan P1 yaitu $34,93 \%$, lalu perlakuan P3 yaitu $34,46 \%$, P0 yaitu $33,82 \%$, P2 yaitu 32,91\%, perlakuan P4 yaitu 32,30\%, P5 25,84\% dan terendah pada perlakuan P6 yaitu $17,44 \%$. Gulma Cyperus rotundus memiliki nilai SDR tertinggi pada perlakuan P3 yaitu 47,82, lalu perlakuan P3 yaitu $23,91 \%$, perlakuan P2 yaitu 20,17\%, perlakuan P1 20,05\%, perlakuan P5 yaitu $17,03 \%$, perlakuan $\mathrm{P} 415,71 \%$, perlakuan $\mathrm{P} 0$ $14,82 \%$ dan terendah pada perlakuan P6 yaitu $14,05 \%$. Gulma Cromolaena odorata hanya tumbuh diperlakuan P0 dengan nilai SDR sebesar 13,83\%.

Gulma Boreria sp. memiliki nilai SDR tertinggi pada perlakuan P6 yaitu $28,10 \%$, lalu perlakuan P5 yaitu 23,53\%, perlakuan P3 yaitu $21,79 \%$, perlakuan P1 yaitu $15,35 \%$, perlakuan P0 yaitu $13,85 \%$, perlakuan P4 yaitu $13,28 \%$ dan terendah pada perlakuan P2 yaitu 10,03\%. Gulma Amarhantus sp. hanya tumbuh pada perlakuan P0 dengan nilai SDR yaitu 13,83\%. Gulma Digitaria sp. memiliki nilai SDR tertinggi pada perlakuan P0 yaitu $1,57 \%$, selanjutnya perlakuan $\mathrm{P} 4$ yaitu $1,55 \%$ dan perlakuan P3 yaitu $1,34 \%$. sedangkan pada perlakuan P1, P2, P5 dan P6 gulma ini tidak tumbuh. Gulma Ageratum conyzoides memiliki nilai SDR tertinggi pada perlakuan P2 yaitu $26,85 \%$, selanjutnya pada perlakuan P4 yaitu $22,20 \%$, perlakuan P6 yaitu 18,16\%, perlakuan P1 yaitu $13,49 \%$, perlakuan P5 yaitu $13,46 \%$ dan perlakuan P0 yaitu $11,84 \%$ sedangkan pada perlakuan P3 gulma ini tidak tumbuh. Gulma Eleucine indica hanya tumbuh pada perlakuan P0 dengan nilai SDR sebesar yaitu $1,11 \%$.

Gulma Paspalum sp. memiliki nilai SDR tertinggi pada perlakuan P0 yaitu 7,82\% dan pada perlakuan P4 yaitu $2,78 \%$ sedangkan pada perlakuan P1, P2, P3, P5 dan P6 gulma ini tidak tumbuh. Gulma Blumea sp. hanya tumbuh pada perlakuan P0 dengan nilai SDR yaitu $0,36 \%$. Gulma Asystasia sp. memiliki nilai SDR tertinggi pada perlakuan P5 yaitu $7,38 \%$, perlakuan $\mathrm{P} 2$ yaitu $4,00 \%$, perlakuan $\mathrm{P} 1$ yaitu 0,30 dan pada perlakuan P0, P3, P4 dan P6 gulma ini tidak tumbuh. Gulma Echinocloa co memiliki nilai SDR tertinggi pada perlaku; 39 yaitu $7,11 \%$, selanjutnya adalah perlakuan $\mathrm{Pl}$ $6,79 \%$, perlakuan P5 5,32\%, perlakuan yaitu $4,49 \%$ sedangkan pada perlakuan P0, P2 dan P4 gulma ini tidak tumbuh.

Gulma Cynodon dactylon memiliki nilai SDR tertinggi pada perlakuan $\mathrm{P} 4$ yaitu $12,18 \%$, selanjutnya pada perlakuan P6 yaitu 11,02\%, perlakuan P1 yaitu $8,99 \%$, perlakuan P5 yaitu $7,44 \%$, perlakuan P3 yaitu $7,04 \%$ dan terendah pada perlakuan P2 yaitu 4,94\% sedangkan pada perlakuan P0 gulma ini tidak tumbuh. Gulma Scoparia dulcis memiliki nilai SDR tertinggi pada perlakuan P3 yaitu $6,97 \%$ selanjutnya perlakuan P6 $4,12 \%$, perlakuan $\mathrm{P} 2$ yaitu $1,10 \%$ sedangkan pada perlakuan P0, P1, P4 dan P5 gulma ini tidak tumbuh.

Berdasarkan hasil pengamatan pertumbuhan tanaman kedelai di atas dapat dilihat bahwa perlakuan formulasi terbaik adalah perlakuan P6 yaitu formulasi rizobakteri $P$. aeruginosa $\mathrm{A}_{08}$ dalam bahan pembawa serbuk arang sekam karena formulasi ini dapat menghambat pertumbuhan gulma hal ini juga dapat dilihat pada hasil pengamatan nilai SDR gulma, dimana perlakuan terbaik ditunjukkan oleh formulasi $P$. aeruginosa $\mathrm{A}_{08}$ dalam bahan pembawa arang sekam (P6). Isolat $\mathrm{A}_{08}$ mampu menghambat pertumbuhan gulma Cleome rutidosperma yang merupakan gulma paling dominan pada pertanaman kedelai menjadi $17,44 \%$ jika dibandingkan dengan kontrol yaitu 33,82\%. Hasil penelitian Hisnawati (2014) menunjukkan bahwa isolat $\mathrm{A}_{05}$ merupakan isolat rizobakteri yang menghasilkan IAA (15,8 ppm), sedangkan $\mathrm{A}_{08}$ memiliki kemampuan menghasilkan HCN (+++/sangat kuat), IAA (16,0 ppm), memfiksasi $\mathrm{N}$ dan melarutkan fosfat. Kemampuan rizobakteri menekan pertumbuhan gulma tergantung dari konsentrasi $\mathrm{HCN}$ yang diproduksi oleh isolat yang digunakan (Kremer and souissi, 2001; Flores-Vegas and O'Hara, 2006).

Bahan pembawa arang sekam merupakan bahan cocok untuk isolat rizobakteri $P$. aeruginosa $\left(\mathrm{A}_{08}\right)$ dan tidak mengurangi kemampuan isolat atau menjaga stabilitas isolat tersebut sebagai bioherbisida hal ini disebabkan karena bahan tersebut tidak mengandung toksin. Berdasarkan penelitian sebelumnya oleh Rakian (2014) bahwa isolat $\mathrm{A}_{08}$ memiliki daya hambat terhadap daya berkecambah $A$. conyzoides mencapai $68 \%$ dan penghambatan terhadap kecepatan tumbuh relatif hingga $58,6 \%$ etmal $^{-1}$. Hal ini juga sejalan dengan penelitian Fermin (2015) bahwa hasil pengamatan uji stabilitas DRB sebagai bioherbisida yaitu terhadap komponen perkecambahan benih gulma $A$. convzoides, perlakuan yang terbaik ditunjukan oleh $40 \quad \mathrm{~A}_{08}$ yang berasal dari bahan pembawa talek ang sekam pada umur 12 minggu. Isolat $\mathrm{A}_{08}$ tersebut mampu menghambat daya berkecambah $A$. conyzoides mencapai $68 \%$, menghambat potensi tumbuh maksimum $54,66 \%$ dan $60 \%$, kecepatan tumbuh relatif $57,51 \%$ etmal $^{-1}$ dan $56,81 \%$ etmal $^{-1}$, keserampakkan tumbuh $62,67 \%$ dan $61,34 \%$, serta menghambat pertumbuhan panjang akar masingmasing adalah $78,23 \%$ dan $80,64 \%$.

\section{KESIMPULAN}

Berdasarkan hasil penelitian maka dapat disimpulkan bahwa formulasi yang memberikan 
pengaruh paling baik adalah formulasi P6 yaitu formulasi rizobakteri $P$. aeruginosa $\mathrm{A}_{08}$ dalam bahan pembawa serbuk arang sekam, karena formulasi ini mampu menekan pertumbuhan gulma Cleome rutidosperma D.C dan Cyperus rotundus L. yang merupakan gulma dominan pada pertanaman kedelai berdasarkan nilai kerapatan mutlak, dominansi mutlak dan nilai SDR yang lebih kecil jika dibandingkan kontrol.

\section{DAFTAR PUSTAKA}

Adisarwanto, 2005. Budidaya dengan Pemupukan yang Efektif dan Pengoptimalan Peran Bintil Akar. Jakarta: Penerbit Rajawali Pers.

Bai Y., pan B., Charles T.C, Smith D.L., 2002. Coinoculation dose and root zone temperatur for plant growth promoting rhyzobacteria on soybean (Glycyne max (L.) Merr grown in soil less media. Soil Biol Biochem 34 : 1953-1957.

Biswas, M.M., R. Zdor, dan C. Miller, 2009. Using Gene Fusions to Study Cyanogenesis in a Weed Deleterious Rhizobacterium. Proceedings IXth International Bioherbicide Group Workshop. p.20-22.

Carvalho D.D.C., D.F Oliveira, R.S.B. Correa, V.P. Campos, R.M. Guimaraes and J.L. Coimbra. 2007. Rhizobacteria able to produce phytotoxic metabolites. Brazilian Journal of Microbiology, Vol. 38 No. 1 p. 759-765.

Dhalimi, A. 2003. Pengaruh Sekam dan Abu sekam Terhadap Pertumbuhan Dan Kematian Tanaman Panili (Vanilla planifolis Andrews) di Pembibitan. Balai Penelitian Tanaman Rempah dan Obat, Buletin TRO Vol. XIV No. 2.

Fermin, Uli. 2015. Efektivitas Jenis Bahan Pembawa Rizobakteri Indigenos Gulma Berpotensi sebagai Bioherbisida dan Pemacu Pertumbuhan pada Pertanaman Kedelai (Glycine max (L.) Merril). Tesis. Universitas Halu Oleo.

Flores-Vargas, R D., dan G W, O’Hara, 2006. Isolation and characterization of rhizosphere bacteria with potential for biological control of weed in vineyard. Journal of applied Microbiology, Vol. 100 No.1 p. $946-954$

Isa Ishak, 2011. Penetapan asam lemak linoleat dan linolenat pada minyak kedelai secara kromatografi gas. Saintek Vol 6, NO 1.p 1-6.

Kementerian Pertanian, 2015. Jurnal Statistik Ekspor Impor Komoditas Pertanian 2001-20013. Direktorat Jendral Pengolahan dan Hasil Pertanian.
Disarankan untuk menggunakan formulasi P6 sebagai pengendali hayati gulma, tetapi masih diperlukan pengujian lebih lanjut sampai pada produksi kedelai untuk melihat kualitas dan kuantitas dari biji kedelai yang dihasilkan. Perlu dilakukan juga analisis vegetasi awal sebelum pembukaan lahan, untuk melihat perbedaan jenis gulma yang tumbuh sebelum dan sesudah aplikasi.

Kementerian Pertanian, 2016. Buletin Ekspor Impor Komoditas Pertanian. Vol. VII No. 1.

Kementerian Pertanian, 2016. Luas Panen Kedelai Menurut Provinsi.

Kementerian Pertanian, 2016. Produksi Kedelai Menurut Provinsi

Kementerian Pertanian, 2016. Produkstivitas Kedelai Menurut Provinsi.

Kremer, R.J. and A.C. Kennedy. 1996. Rhizobacteria As Biocontrol Agents of Weeds. Weed Technology, Vol. 1996 No.10 p.601-609.

Kremer, R.J., and Souissi, T., 2001. Cyanide production by rhizobacteria and potential for suppression of weed seedling growth. Current Microbiol.Vol. 43 No.1 p.182-186.

Kremer, R.J. 2006. Deleterious rhizobacteria. In S. gnanamanickam (ed.), Plant-associated bacteria, Kluwer Academic Publishers, Dordrecht, Netherlands (in press).

Moenandir J., 1993. Pengantar ilmu dan Pengendalian Gulma. PT. Raja Grafindo Persada. Jakarta.

O'Hara, G., 2005. Biological control of weeds in vineyards. Murdoch University. Final Report to Grape and Wine Research \& Development Corporation Project Number: MU 00/1.

Sembodo, D.R.J., 2010. Gulma dan Pengelolaannya. Yogyakarta:Penerbit Graha Ilmu. 166p.

Sutariati, G.A.K. dan A. Wahab, 2012. Karakter Fisiologis dan Kemangkusan Rizobakteri Indigenus Sulawesi Tenggara sebagai Pemacu Pertumbuhan Tanaman Cabai. J. Hort.Vol. 22 No. 1 p. 57-64.

Violic, A.D., 2000. Integrated crop management. In: R.L. Paliwal, G. Granados, H.R. Lafitte, A.D. Violic, and J.P. Marathee (Eds) Tropical Maize improvement and production. FOA Plant production and protection. 